This item was submitted to Loughborough's Research Repository by the author.

Items in Figshare are protected by copyright, with all rights reserved, unless otherwise indicated.

Community scale, decentralised anaerobic digestion for energy and resource recovery

PLEASE CITE THE PUBLISHED VERSION

http://dx.doi.org/10.1109/COGEN.2016.7728947

PUBLISHER

(C) IEEE

VERSION

AM (Accepted Manuscript)

LICENCE

CC BY-NC-ND 4.0

REPOSITORY RECORD

Radu, Tanja, Richard E. Blanchard, Vincent Smedley, Andrew D. Wheatley, Abdul Salam, and Chettiyappan Visvanathan. 2019. "Community Scale, Decentralised Anaerobic Digestion for Energy and Resource Recovery”. figshare. https://hdl.handle.net/2134/23392. 


\section{Community Scale, decentralised Anaerobic Digestion for energy and resource recovery}

\author{
Tanja Radu ${ }^{1}$, Richard Blanchard ${ }^{2}$, Vincent Smedley ${ }^{1}$ \\ and Andrew Wheatley ${ }^{1}$ \\ ${ }^{1}$ School of Civil and Building Engineering and ${ }^{2}$ School of \\ Mechanical, Electrical and Manufacturing Engineering, \\ Loughborough University, Loughborough, UK \\ T.Radu@lboro.ac.uk
}

\author{
Abdul Salam and Chettiyappan Visvanathan \\ Asian Institute of Technology (AIT) \\ Bangkok, Thailand
}

\begin{abstract}
The paper describes "Community scale, decentralized anaerobic digestion for energy and resource technology" which is a joint UK-Thailand project much in line with the current aims of the Thai Government for decentralized energy generation. The use of food waste for biogas generation by the process of anaerobic digestion provides multiple benefits: decreased energy dependency, nutrient preservation and recycling, and reduced greenhouse gas emissions. It is also promoted in the remoter Scotland and Wales of the UK.
\end{abstract}

The aim of the project is the design and deployment of small scale digesters and their networking into remotely monitored units. Here, we are describing initial design of the reactors and some issues associated with using food waste as substrate. Based on the literature, we have also estimated the reactors performance to be $0.40-0.50 \mathrm{~m}^{3} / \mathrm{kg}$ of feedstock for biogas production.

Index Terms-- biogas, community scale, decentralized energy, food waste

\section{INTRODUCTION}

The combined benefits of waste treatment and need for sustainable energy has led to a recent rapid expansion of Anaerobic Digestion in Europe. In the UK for example while the installed capacity of sewage sludge fed digesters, as the process of choice, has remained fairly constant between 2012-2014, the capacity of non- sewage sludge digesters (i.e. food waste, energy crop) has almost doubled during the same period of time, from 119 to $216 \mathrm{MWe}$ [1] (Table 1). A similar trend is expected in Thailand, especially considering Governmental aim (summarized in the AEDP plan [2]) for decreased dependence on imported energy and to also increase energy provision at community scale by decentralized generation.

This project "Community Scale, decentralised Anaerobic Digestion for energy and resource recovery" is a joint project between Asian Institute of Technology (AIT) and Loughborough University, aiming to provide decentralized energy from waste for remote communities on a small scale. The project goal is to develop designs for small package anaerobic digesters taking into account the mixing needs according to feedstock characteristics and demonstrate this design at an appropriate scale. Anaerobic digestion needs monitoring and control in order to achieve optimal performance. Process monitoring is easier and available at an industrial scale but becomes very expensive at a small scale.

The design of smaller biogas reactors also raises fundamental issues concerning the energy needed for pretreatment and mixing for optimum gas yields when feeding combinations of dry and wet food, domestic and agricultural wastes. In Thailand it is common to feed all types of waste on demand and accept long retention times (RT) to overcome poor degradability. In the UK, the approach has been to blend/dilute feed-stocks to improve mixing and reduce RT. There are innovative ways to overcome these basic problems of control and mixing. In this work we will use simulation modelling to identify the best strategies for dealing with varying heterogeneous feed-stocks. In terms of a low-cost monitoring platform we have laboratory tested an autonomous, real time measurement system for $\mathrm{CO}_{2}$ and methane, suitable for scale up in the project described here. We intend to focus on design and testing of on-line remote, machine monitoring for the control of multiple digesters, providing support for a network of decentralized digesters.

Here, we describe the design stages used for small scale, remotely monitored digesters.

\section{BIOREACTOR DESIGN}

The reactor is designed for decentralized use, with a low energy footprint and the possibility to be used with renewable intermittent energy resources. The design is based on a $1.3 \mathrm{~m}^{3}$ prefabricated polypropylene storage tank $\left(1 \mathrm{~m}^{3}\right.$ operating volume) adapted as the digester for food waste. 
Mixing in the digester is by a re-circulation loop. It is equipped with a positive displacement pump for feeding and a centrifugal pump for recirculation and removal of digestate. Both feeding and digestate removal storage tanks are equipped by load cells for mass balance monitoring.

The digester is double walled with hot water circulating in a tube between the walls to maintain constant temperature inside of the reactor. A $3.5 \mathrm{~kW}$ electric heating element is paired with small double disc domestic heating pump. Temperature sensors monitor temperature inside of the reactor, that of the heated water and the ambient temperature. In colder climates, such as in UK, insulation of the reactor is important and was achieved using aluminium foil blanket and polyurethane insulation.

Performance will be continuously monitored and recorded using customized software with graphical interface to display current data from the bioreactor. The control system contains low-power micro controllers to regulate and monitor bioreactor temperature, recirculation pump and measure biogas flow. A sub routine monitors electrical energy consumption to provide information about parasitic energy and net benefit of the system. As noted a newly available remote gas monitoring system has been added. The system was originally developed for monitoring remote, closed, landfill sites, these are the first trials to monitor several digesters simultaneously. This independent autonomous monitoring platform is equipped with $\mathrm{CH}_{4}, \mathrm{CO}_{2}$, $\mathrm{O}_{2}, \mathrm{NH}_{3}$, pressure and temperature sensors. This will enable remote access to the data and enable connecting digesters into decentralized network.

In addition to biogas yield, quality, and flow rate, the stability of reactor will be checked occasionally by monitoring wet stability parameters $(\mathrm{pH}$, volatile fatty acids, ammonia).

\section{FOOD WASTE: COMPOSITION, AND BIOGAS YIELD}

Various compositions and pre-treatment options of waste will be examined. Food waste composition is one of the determining factors in the project, as diets in Thailand and UK differ significantly. In order to standardize typical food waste for the UK region, WRAP has issued synthetic food waste recipe [3], [4] which contains staples of British food, as shown in Table 1, others are available for the USA and Australia.

The Thai recipe is expected to differ from the one shown below. For example, a higher percentage of starchy rice is anticipated. One of the project aims will be studying these differences in terms of food waste compositions and availability in Thailand and UK. Pre-treatment of the food waste will be based on UK industrial standard of reducing the particle size to approximately $6 \mathrm{~mm}$ using ball or hammer mills or macerators.

In the experimental work, after the initial inoculation and start up of the digester, synthetic food waste will be used as a feedstock. This will enable predictable, uniform waste composition and easier interpretation of the data.

TABLE 1. Simulated UK food waste recipe [3],[4]

\begin{tabular}{|c|c|c|c|}
\hline \multicolumn{2}{|c|}{ Recipe $\%$ by weight } & \multicolumn{2}{|l|}{$\mathrm{g} / \mathrm{kg}$ of recipe } \\
\hline Vegetables & 38 & Potato & 237 \\
\hline & & Onion & 40 \\
\hline & & Carrot & 37 \\
\hline & & Cabbage & 26 \\
\hline & & Lettuce & 21 \\
\hline & & Tomato & 19 \\
\hline \multirow[t]{2}{*}{ Fruit } & 21 & Banana & 114 \\
\hline & & Apple & 96 \\
\hline Bakery & 16 & Bread & 160 \\
\hline \multirow[t]{2}{*}{ Meat and Fish } & 11 & Beef & 55 \\
\hline & & Pork, Ham and Bacon & 55 \\
\hline Drink & 10 & Tea & 100 \\
\hline Dairy & 4 & Butter Milk & 40 \\
\hline
\end{tabular}

A summary of the food waste anaerobic digestion performance reported in literature is shown in Table 2.

TABLE 2. Comparison of AD performance on food waste

\begin{tabular}{|c|c|c|c|c|}
\hline OLR & SGY & HRT & TS & \\
\hline $\mathrm{KgVS} / \mathrm{m}^{3}$ & $\begin{array}{c}\mathrm{m}^{3} \mathrm{CH}_{4} / \mathrm{VS} \\
\text { added } \\
\text { corrected to } \\
\text { STP }\end{array}$ & Days & $\%$ & Reference \\
\hline 5 & 0.43 & 38 & 24 & Banks et at 2012 [5] \\
\hline 9.2 & 0.45 & 16 & 10.3 & Nagao et al 2012 [6] \\
\hline 2.6 & 0.34 & 2.5 & 10 & Jobling-Purser, 2015 [4] \\
\hline 2 & 0.43 & 117 & 25 & Tampio et al 2014 [7] \\
\hline 6 & 0.44 & 39 & 25 & Tampio et al 2014 [7] \\
\hline
\end{tabular}

A large variation of the total solids(10-25 \%TS), fibre and a wide range of retention times (2.5-117 days) were reported, but specific gas yield expressed in $\mathrm{m}^{3}$ of $\mathrm{CH}_{4}$ per $\mathrm{kg}$ of volatile solids added. There is agreement however in most cases that there is a specific methane yield of over $0.4 \mathrm{~m}^{3} / \mathrm{kg}$. Table 3 shows an example predicted bioreactor performance from the control routine when fed by $10 \mathrm{~kg}$ of wet food waste per day. Under the assumption of $30 \% \mathrm{TS}, 80 \%$ removal efficiency and specific gas yield of $0.5 \mathrm{~m}^{3} / \mathrm{kg} \mathrm{VS}$, a biogas yield of $50 \mathrm{l} / \mathrm{h}$ is expected, which will correspond to 7.67 $\mathrm{kWh} /$ day of biogas energy. Our previous laboratory scale work with the design reported suggests this is achievable with a 15-20 day retention time with good mixing. 
TABLE 3. Prediction of the bioreactor performance based on $10 \mathrm{~kg} /$ day feeding

\begin{tabular}{|c|c|c|c|c|c|c|c|c|}
\hline $\begin{array}{l}\text { Wet weight of } \\
\text { waste } \mathrm{kg} / \text { day }\end{array}$ & $\begin{array}{c}\text { Dry solids } \\
\text { weight } \\
\text { kg/day } \\
\text { assume } 30 \%\end{array}$ & $\begin{array}{l}\text { Material } \\
\text { removed } \\
\mathrm{kg} / \text { day } \\
\text { assume } \\
\text { process is } \\
80 \% \text { efficient }\end{array}$ & $\begin{array}{c}\text { Daily biogas } \\
\text { yield } \mathrm{m}^{3} / \mathrm{day} \\
\text { assumes } \\
0.5 \mathrm{~m}^{3} \\
\text { biogas } / \mathrm{kg}\end{array}$ & $\begin{array}{c}\text { Biogas } \\
\text { yield } \\
\mathrm{m}^{3} / \mathrm{h}\end{array}$ & $\begin{array}{c}\text { Biogas } \\
\text { yield } \\
\text { I/h }\end{array}$ & $\begin{array}{c}\text { Biogas } \\
\text { flow } \\
\mathrm{l} / \mathrm{m}\end{array}$ & $\begin{array}{c}\text { Biogas } \\
\text { energy } \\
\text { MJ/day } \\
\text { assumes } \\
23 \mathrm{MJ} / \mathrm{m}^{3}\end{array}$ & $\begin{array}{c}\text { Biogas } \\
\text { energy } \\
\text { kWh/day } \\
\text { assumes } \\
23 \mathrm{MJ} / \mathrm{m}^{3}\end{array}$ \\
\hline 10 & 3 & 2.4 & 1.2 & 0.05 & 50 & 0.83 & 27.6 & 7.67 \\
\hline
\end{tabular}

\section{CONCLUSIONS}

In this paper the initial design towards building small scale standard prefabricated $\mathrm{AD}$ reactor for decentralized biogas along with prediction of its performance based on values previously obtained at laboratory scale and reported in literature. Food waste would be used in digesters built both in Thailand and UK. The objective is networking three digesters with the remotely monitored data being sent to a joint online portal, providing an easy access for operators.

\section{ACKNOWLEDGMENT}

This work has been funded by the British Council Newton Fund Institutional Links Grant agreement 216423359

\section{REFERENCES}

[1] DECC, 2015. Special feature - Renewable energy in 2014, Digest of United Kingdom energy statistics (DUKES) (WWW Document). URL

https://www.gov.uk/government/uploads/system/uploads/atta chment_data/file/437937/Renewable_energy_in_2014.pdf (accessed 4.08.16).
[2] The Department of Alternative Energy Development and Efficiency (DEDE), Thailand, Alternative Energy Development Plan: AEDP 2012-2021

[3] WRAP, Household Food and Drink waste in the UK, final report, 2012,

http://www.wrap.org.uk/sites/files/wrap/Household_food_and _drink_waste_in_the_UK___report.pdf, (accessed 5.08.16).

[4] Jobling-Purser, B., (2015) Improving volatile fatty acid, hydrogen and ethane production from food waste substrates for optimised resource recovery. PhD Thesis, University of South Wales, 2015.

[5] Banks, C.J., Zhang, Y., Jiang, Y., Heaven, S., 2012. Trace element requirements for stable food waste digestion at elevated ammonia concentrations. Bioresour Technol. 104, 127-135.

[6] Nagao, N.,Tajima, N., Kawai, M., Niwa, C., Kurosawa, N., Matsuyama, T., Yusoff, F.M., Toda, T., 2012. Maximum organic loading rate for the single-stage wet anaerobic digestion of food waste. Bioresour. Technol. 118, 210-218.

[7] Tampio, E., Ervasti, S., Paavola, T., Heaven, S., Banks, C., Rintala, J., 2014. Anaerobic digestion of autoclaved and untreated food waste. Waste Manag. 34, 370-377. 